\title{
PERANAN PIMPINAN DAN GURU DALAM PEMBINAAN AKHLAK SISWA PADA MADRASAH TSANAWIYAH NEGERI KUPANG
}

\author{
Marwan Gozali, Muhammad Tamrin
}

\author{
Universitas Muhammadiyah Kupang \\ Jl. K.H.Ahmad Dahlan Kayu Putih, Kupang, Nusa Tenggara Timur \\ e-mail: gozalimarwan15@gmail.com, khasa tamrin@yahoo.com
}

\begin{abstract}
Abstrak: Penelitian ini bertujuan untuk menganalisis: 1) kebijakan kepemimpinan terhadap perkembangan moral siswa, 2) pelaksanaan bimbingan guru dalam melaksanakan akhlak siswa, 3) faktor-faktor pendukung dan penghambat dalam perkembangan moral, 4) Keberhasilan guru dalam mengembangkan moral siswa. Penelitian ini dilakukan di Madrasah Tsanawiyah Negeri Kupang. Penelitian ini dilakukan dengan metode deskriptif analitik dengan pendekatan kualitatif. Hasil penelitian menunjukkan bahwa kebijakan kepemimpinan terhadap perkembangan akhlak siswa di MTs. Negeri Kupang yaitu dengan membuat peraturan sekolah yang mendukung pengembangan akhlak siswa, pelaksanaan bimbingan guru dalam mengembangkan akhlak siswa dapat dilihat dari perpaduan pembelajaran agama islam dengan penyampaian materi pelajaran yang berkaitan dengan akhlak dan kegiatan ekstrakurikuler. Faktor pendukung pengembangan akhlak siswa adalah adanya regulasi. madrasah mengenai kewajiban siswa mengikuti kegiatan ekstrakurikuler yang telah ditentukan jadwal, adanya program kebijakan kepemimpinan madrasah yang terkait dengan terciptanya kondisi sekolah yang bernuansa keramahan, terdapat faktor penghambat. Keberhasilan pembinaan akhlak siswa dapat dikatakan kurang maksimal karena indikator keberhasilannya sama dengan perubahan karakter siswa menjadi lebih baik.
\end{abstract}

Kata Kunci: Kepala Madrasah, Pembinaan Moral, Guru

Abstract: This study aims to analyze: 1) leadership policies on student moral development, 2) implementation of teacher guidance in implementing student morals, 3) supporting and inhibiting factors in moral development, 4) The success of teachers in developing student morale. This research was conducted at Madrasah Tsanawiyah Negeri Kupang. This research was conducted with a descriptive analytic method with a qualitative approach. The results showed that the leadership policy towards the moral development of students in MTs. Negeri Kupang, namely by making school regulations that support the development of student morals, the implementation of teacher guidance in developing student morals can be seen from the combination of Islamic religious learning with the delivery of subject matter related to morals and extracurricular activities. The supporting factor for the development of student morals is the existence of regulations. madrasah regarding the obligations of students to take part in extracurricular activities that have been determined by the schedule, the existence of a madrasah leadership policy program related to the creation of school conditions that have a nuanced hospitality, there are inhibiting factors. The success of students' moral development can be said to be less than optimal because the indicators of success are the same as changes in student character for the better.

Keywords: Principal of Madrasah, Moral Development, Teacher 
PENDAHULUAN

Pendidikan yang diyakini sebagai salah satu upaya dalam rangka meningkatkan kualitas hidup manusia ini, pada ointinya bertujuan untuk memanusiakan manusiam mendewasakan serta memngubah perilaku serta meningkatkan kualitas menjadi lebih baik. Pada kenyataannya, pendidikan bukanlah suatu upaya yang sederhana, melainkan sebagai suatu sistem yang di dalamnya mengandung elemen-elemen yang beraneka ragam dan saling berkaitan serta kegiatankegiatan yang dinamis dan penuh tantangan. Pendidikan tidaklah statis melainkan akan selalu berubah seiring dengan perubahan dan perkembangan zaman. Itulah sebabnya, pendidikan senantiasa memerlukan upaya perbaikan dan pembinaan sejalan dengan semakin tingginya kebutuhan dan tuntutan kehidupan masyarakat. (Said, 2003)

Berbicara tentang perbaikan dan pembinaan pendidikan, maka sekolah sebagai sentral dan wadah pendidikan adalah salah satu elemen penting yang harus mendapatkan perhatian secara lebih serius dan sungguh-sungguh. Sekolah sebagai institusi (lembaga) pendidikan yang merupakan wadah tempat proses pendidikan dilakukan, memiliki sistem yang kompleks dan dinamis. Dalam kegiatannya, sekolah adalah tempat yang bukan hanya sekedar tempat berkumpul guru dan murid, melainkan berada dalam satu tatanan sistem yang rumit dan saling berkaitan. Oleh karena itu, sekolah dipandang sebagai organisasi yang membutuhkan pengelolaan. Lebih dari itu, kegiatan organisasi sekolah adalah mengelola sumber daya manusia (SDM) yang diharapkan menghasilkan lulusan yang berkualitas, sesuai dengan tuntunan kebutuhan masyarakat, serta pada gilirannya lulusan sekolah diharapkan dapat memberikan kontribusi kepada pembangunan bangsa. Selanjutnya sekolah juga dipandang sebagai suatu organisasi yang didesain untuk dapat berkontribusi terhadap upaya pembinaan kualitas hidup bagi masyarakat suatu bangsa. (Asraf, 1996).

Sebagai salah satu upaya pembinaan kualitas sumber daya manusia serta pembinaan derajat sosial masyarakat, bangsa dan Negara. Sekolah sebagai institusi pendidikan perlu dikelola, dimenej, diatur, dan diberdayakan agar sekolah dapat menghasilkan produk atau hasil secara optimal. (Fattah, 2003)

Sekolah sebagai institusi termpat masyarakat berharap dituntut untuk melakukan perubahan dan perbaikan guna mencapai pendidikan bermutu, sebagaimana yang diharapkan masyarakat tersebut. Perubahan dan perbaikan pendidikan tersebut dapat tercapai bila kepala sekolah mampu menerapkan manajemen persekolahan yang efektif. (Zuhairi, 1992).

Salah satu bidang manajemen pendidikan pada tingkat persekolahan yang cukup mempunyai peran senttral adalah manajemen berbasis pembinaan akhlak siswa. Manajemen pembinaan akhlak siswa yang menyangkut pengurusan serta layanan dalam hal-hal yang berkaitan dengan siswa di suatu sekolah mulai dari 
perencanaanpenerimaan siswa, pembinaan siswa selama berada di sekolah sampai dengan siswa menamatkan pendidikannya, merupakan bagian yang tidak terpisahkan dari manajemen pendidikan si suatu sekolah/lembaga yang dilaksanakan dalam bentuk kebijakan pimpinan dalam hal ini kepala sekolah dan diperankan oleh para guru khususnya guru agama Islam. (Asmara, 2020), (Masyari, 1990).

Ditegaskan oleh Muhtar Efendi bahwa pengertia manajemen itu mengandung makna secara substansial yang meliputi manajemen berdasarkan akhlak yang merupakan nilai fundamental dalam ajaran Islam. Bahwa kehadiran Islam yang dibawa oleh Rasulullah adalah penyempurnaan akhlak manusia. Untuk itu para pemimpin atau manager harus mengamalkan akhlak mulia atau luhur, (jujur, adil, sabar, rendah hati, amanah, saling menghormati, dan sebagainya) serta penyelenggaraan manajemen dalam organisasi tentu harus berpedoman pada perilaku akhlakul karimah. (Efendi, 1989)

Adapun yang menjadi fokus dalam penelitian penulis adalah berkaitan dengan kondisi riil yang terjadi di Madrasah Tsanawiyah Negeri Kupang bahwa lembaga pendidikan formal yang berbeda dengan sekolah umum lainnya. Hal yang membedakan tersebut adalah Madrasah Tsanawiyah Negeri Kupang dalam pembinaan para siswa lebih relatif mudah menangani penyimpangan perilaku, dan kenakalan para siswa yang sulit diatasi oleh lembaga pendidikan umum lainnya. Ini pula dapat terlihat dari beberapa asumsi atau pandangan masyarakat Kota Kupang menilai bahwa keberadaan Madrasah Tsanawiyah Negeri Kupang adalah salah satu lembaga pendidikan Islam yang dapat mengatasi masalah-masalah para peserta didik yang pindahan dari lembaga selain Madrasah Tsanawiyah Negeri Kupang. Satu pertanyaan besar yang muncul kemudian adalah bagaimanakah pimpinan dan guru Madrasah Tsanawiyah Negeri Kupang mampu melaksanakan pembinaan akhlak siswa yang efektif dan mampu menghasilkan sosok siswa sebagaimana yang diharapkan oleh masyarakat yang sesuai dengan tujuan pendidikan akhlak di sekolah.

\section{METODE PENELITIAN}

Metode penelitian ini dilakukan dengan metode deskriptif analitik dengan pendekatan kualitatif. Penggunaan metode dan pendekatan ini berawal dari tujuan pokok penelitian yaitu mendeskripsikan dan menganalisa data dan informasi sesuai dengan keadaan sebenarnya (Moloeng, 2007) terhadap peranan pimpinan dan guru dalam pembinaan akhlak siswa pada Madrasah Tsanawiyah Negeri Kupang. Penelitian ini menggunakan teknik pengumpulan data observasi, wawancara, dan studi dokumentasi. Adapun eknik analisis data yang dipergunakan dalam penelitian ini ialah analisis deskriptif. Maksudnya analisa temuan penelitian dalam bentuk pendeskripsian. Analisis dalam hal ini yang dimaksud dengan interpretasi dari penulis. Untuk menjamin keabsahan data penelitian ini menggunakan teknik pengujian kredibilitas (kepercayaan), transferabilitas

(keterlibatan), 
dependabilitas (kebergantungan), dan konfirmabilitas (kepastian) yang terkait dengan proses pengumpulan dan analisis data.

\section{HASIL DAN PEMBAHASAN}

\section{A. Kebijakan Pimpinan/Kepala} Madrasah Tentang Pembinaan Akhlak Siswa Mts Negeri Kupang

1. Kebijakan dan kedudukan Pimpinan/ Kepala Madrasah

a. Kepala Sekolah Berperan Sebagai Manajer

Peran ini mengandung makna bahwa kepala Sekolah/Madrasah itu harus mampu merencanakan, melaksanakan dan mengevaluasi berbagai program sekolah. Kepala sekolajh harus mampu mengelola dan mengorganisasikan berbagai sumber daya yang dimiliki sekolah agar dapat diberdayagubakan secara optimal dalam mencapai tujuan yang telah ditetapkan. Di samping itu kepala sekolah juga harus dapat mempertanggungjawabkan seluruh tindakannya tersebut kepada seluruh warga sekolah.

\section{b. Kepala Sekolah/Madrasah sebagai Administrator}

Peranan ini mempunyai pengertian bahwa kepala madrasah harus mempunyai kemampuan dan keterampilan dalam melakukan berbagai pengorganisasian madrasah. Kepala sekolah harus mengelola administrasi yang berhubungan dengan proses pendidikan di madrasah seperti kurikulum, administrasi siswa personalia, administrasi sarana prasarana, administrasi kearsipan dan administrasi keuangan. c. Kepala Madrasah sebagai penyedia (supervisor)

Peran ini mengandung pengertian bahwa kepala madrasah/sekolah harus mampu melakukan kegiatan supervise bagi seluruh komponen yang ada di sekolah. Kegiatan supervise ini dilakukan untuk mengetahui sejauhmana komponen yang ada di madrasah tersebut telah dapat melakukan berbagai tugas dan kewajiban sesuai yang diharapkan.

d. Kepala Madrasah/Sekolah Sebagai Pimpinan

Kepala madrasah merupakan pemimpin yang paling tinggi di sekolah, sehingga kepala sekolah mempunyai kewenangan yang luas dalam mengambil keputusan dan kebijakan untuk sekolahnya. Tetapi meskipun demikian tentu saja kepala sekolah tidak bisa menggunakan kesewenangannya tersebut secara semenamena. Kepala sekolah tetap harus memerhatikan berbagai saran, masukan dari berbagai komponen yang ada di sekolah ketika hendak mengambil sebuah keputusan atau kebijakan.

e. Kepala Madrasah/Sekolah Sebagai Inovator

Kepala sekolah harus mampu mencari, menemukan dan melaksanakan berbagai pembaharuan di sekolah. Kepala sekolah yang innovator ialah kepala sekolah yang selalu merasa tidak puas dengan hasil yang dicapai saat ini, tetapi dia selalu berkeinginan untuk meningkatkan hasilnya lebih baik lagi. Kepala sekolah harus senantiasa 
mengembangkan berbagai kegiatan dan program yang inovatif serta mendorong terjadinya peningkatan mutu yang baik.

f. Kepala Sekolah sebagai Motivator Peran ini mengandung pengertian bahwa kepala sekolah harus mampu memberikan dorongan dan motivasi kepada seluruh komponen yang ada di sekolah untuk senantiasa menjalankan berbagai tugas dan fungsinya tersebut dengan baik. Kepala sekolah harus selalu bertindak dan bersikap yang memberikan semangat dan kekuatan kepada seluruh warga sekolah. Dengan demikian maka, akan tercapai sebuah suasana kerja yang kondusif. Kepala sekolah harus berupaya untuk menghargai berbagai upaya yang dilakukan oleh guru dan stafnya. Karena penghargaan ini merupakan stimulus yang baik untuk memacu kinerja para bawahannya. (Sagala, 2009).

2. Peran Kepala Madrasah dalam Membina Akhlak Siswa

Kebijakan tentang pembinaan akhlak dan prestasi siswa di MTs telah diberikan mandat kepada masing-masing guru bidang studi. Hal tersebut sesuai dengan kebijakan kepala sekolah tentang kebijakan-kebijakan yang berkaitan dengan prinsip-prinsip berdasarkan visi dan misi MTs Negeri Kupang "Unggul dibidang Iptek dan Imtak dan misi-misinya begitu luhur baik bersaing dalam berbagai aspek pendidikan. Dalam rangka meningkatkan kualitas siswa tentu saja harus dapat diwujudkan dengan berbagai program kerja dan struktur organisasi yang dapat dikembangkan. Visi dan misi yang harus sekiranya dibangun secara menyeluruh di kalangan masyarakat luas, dan untuk mewujudkan visi dan misi itu, masyarakat dibutuhkan peran serta dan dukungan dari berbagai pihak baik itu guru, siswa, orang tua, komite sekolah, kementrian agama, bina pendidikan dan olahraga Kota Kupang.

\section{B. Pelaksanaan Bimbingan Guru dalam Pembinaan Akhlak Siswa pada MTs Negeri Kota Kupang}

1. Program Pembelajaran Agama Islam

Pelaksanaan pembinaan akhlak di Madrasah Tsanawiyah Negeri Kupang dikembangkan memalui keterpaduan pada mata pelajaran agama Islam di antaranya adalah Aqidah Akhlak, Fiqih dan AlQur;an Hadits. (Ramayulis, 2008).

2. Kegiatan Ekstra Kurikuler Agama Islam

Mewujudkan pembinaa akhlak, dilakukan kegiatan tambahan sebagai bimbingan pembinaan akhlak di antaranya adalah pengajian rutin, pembinaan ilmu tajwid, kegiatan menghafal surat-surat pendek, kegiatan kultum dan shalat berjamaah, kegiatan muhadharah, kegiatan pesantren kilat dan peringatan hari besar Islam,

\section{Faktor-faktor Pendukung dan Penghambat dalam Pembinaan Akhlak Siswa pada MTs Negeri Kupang}

1. Faktor Pendukung

Faktor pendukung dalam pembinaan akhlak siswa lebih menekankan 
pada aspek-aspek yang menyentuh pada spek kejiwaan atau kerohanian agar siswa itu dapat mengatasi dan menghayati apa yang telah disampaikan oleh guru bidang studi agama Islam. Melihat tingkat dukungan terbinanya pendidikan, dlam hal ini pendidikan akhlak tentu saja harus melihat dari berbagai sudut pandang.

Faktor yang mendukung berhubungan dengan peraturan dalam pembinaan akhlak siswa MTs Negeri Kupang di antaranya adalah pemberian jadwal ekstra kurikuler pengajian Jumat setelah selesai Sekolah. Bagi siswa yang rutin mengikuti pengajian akan dapat terbina dengan baik dan menunjukan perkembangan signifikan. Menjadi sebuah aturan, demi mendukung pembinaan akhlak, dari segi kultur wilayah ketimuran adalah Tegur, sapa dan salam. Pengajian rutinan yang mendukung peraturan madrasah adalah Sanlat (Santri Kilat) yang dilakukannya pada bulan Ramadhan.

\section{Faktor Penghambat}

Siswa tidak dapat melaksanakan ketentuan-ketentuan yang telah ditetapkan oleh aturan sekolah, disebabakan karena kurang memahami nilai-nilai yang telah diajarkan oleh guru bidang studi agama Islam

Faktor penghambat dikategorikan menjadi dua bagian yakni Faktor Intenal dan Faktor ekstenal. Faktor Intenal yang menghambat siswa dalam perkembangan akhlak adalah kebiasaan-kebiasaan yang sudah menjadi karakter seorang siswa dalam kehidupan sehari-hari, seperti sifat malas belajar, ketidakpedulian, terhadap masalah yang terjadi di lingkungannya, tidak disiplin terhadap waktu belajar dan sebagainya. Sedangkan faktor ekstenal yang menghambat perkembangan pembinaan akhlak siswa adalah faktor lingkungan keluarga, faktor kondisi lingkungan sekolah dan faktor lingkungan masyarakat

\section{Keberhasilan Pembinaan Akhlak Siswa pada MTs Negeri Kupang}

Keberhasilan bimbingan guru dalam pembinaan akhlak siswa pada MTs Negeri Kupang dapat dilihat dari berbagai indicator, misalnya keadaan siswa, perilaku baiknya, kesadarannya dalam beragama, dan prestasi belajarnya. Kegiatan pembinaan akhlak di sekolah belum dapat dikatakan berhasil secara maksimal. Hal ini dapat terlihat dengan terdapat beberapa persentase siswa yang mengubah perilakunya. Selanjutnya masih saja ada siswa yang tidak mengubah atau bahkan menurun moralitasnya. Indikator keberhasilannya adalah akhlak siswa menjadi baik. Indikator lainnya adalah faktor guru, siswa, dan masyarakat belum ada kesepakatan dan kesamaan dalam bentuk pembinaan akhlak

\section{SIMPULAN}

Kebijakan pimpinan terhadap akhlak siswa pada MTs Negeri Kupang adalah membuat peraturan-peraturan sekolah yang mendukung pembinaan akhlak siswa, seperti pengajian, shalat berjamaah, dan pemberian reward and punishment bagi 
siapa yang taat dan melanggar peraturan sekolah. Pelaksanaan bimbingan guru dalam pembinaan akhlak siswa bisa dilihat dari peraduan pembelajaran agama Islam dengan penyampaian materi pelajaran yang berhubungan dengan akhlak dan kegiatan ekstra kurikuler secara rutin yang dilaksanakan dengan berbagai kegiatan yang berhubungan dengan perkembangan perilaku atau akhlak siswa. Faktor pendukung pembinaan akhlak adalah adanya peraturan madrasah tentang kewajiban siswa mengikuti kegiatan ekstra kurikuler yang telah ditentukan jadwalnya. Adanya program kebijakan pimpinan madrasah yang berhubungan dengan penciptaan kondisi sekolah yang bernuansa keramahan, seperti program TSS (Tegur, Sapa dan Salam), dukungan para guru dengan keteladanan, pembiasaan perilaku baik di keluarga, masyarakat, dan tidak kalah pentingnya didukung oleh sarana dan prasarana sekolah. Adapun faktor penghambat terdiri dari faktor internal dan faktor eksternal siswa. Faktor internal yang dimaksud di antaranya kondisi kejiwaan, kondisi fisik, dan kebiasaan-kebiasaan buruk siswa. Sdangkan faktor eksternal dipengaruhi oleh tiga faktor yakni lingkungan keluaraga, lingkungan sekolah dan lingkungan masyarakat. Kegiatan pembinaan akhlak di sekolah belum dapat dikatakan berhasil secara maksimal. Hal ini dapat terlihat dengan terdapat beberapa persentase siswa yang mengubah perilakunya. Selanjutnya masih saja ada siswa yang tidak mengubah atau bahkan menurun moralitasnya. Indikator keberhasilannya adalah akhlak siswa menjadi baik. Indikator lainnya adalah faktor guru, siswa, dan masyarakat belum ada kesepakatan dan kesamaan dalam bentuk pembinaan akhlak

\section{DAFTAR PUSTAKA}

Agil, Said. Aktualisasi Nilai-nilai Qur'an dalam sistem pendidikan Qur'an, Jakarta Renika cipta 2003

Asraf, Ali. Horizon Pendidikan Islam, Jakarta Pustaka Firdaus, 1996

Asmara, Pengantar Studi Akhlaq, Jakarta PT Gravindo Persada, 2020

Arifin, M. 2008 Ilmu Pendidikan Islam, Tinjauan Teoritis dan Praktis Berdasarkan Pendekatan Interdisipliner. (Bandung:Remaja Rosda Karya)

Bakri, Umar, Akhlaq Muslim, Bandung Angkasa 1993

Fatah, Nanang, Landasan Manajemen Pendidikan. Bandung PT Remaja Rosda Karya 2001

Masyari, Anwar, Akhlaq Tasawuf, Surabaya Bina Ilmu, 1990

Mukhtar Efendi, 1989. Manajemen Suatu Pendekatan Berdasarkan Ajaran Islam. (Jakarta:Baratata, Karya Aksara)

Maleong, J, Lexy, Metodelogi Penelitian Kualitatif, Bandung Remaja Rosda Karya 2007

Nanang Fattah, 2003. Landasan Manajemen Pendidikan, (Bandung:Remaja Rosda Karya)

Ramayulis, 2008, Ilmu Pendidikan Islam, (Jakrta: Alfabeta)

Sagala, Syaiful. 2009 Kepemimpinan professional Guru dan Tenaga 
Hikmah, Vol. 17, No. 2, Januari-Juni 2020, p-ISSN:1829-8419 e-ISSN: 2720-9040

Kependidikan, (Bandung:

Alfabeta)

Zuhairi, Filsafat Pendidikan Islam, Jakarta

Bumi Aksara 1992. 